\title{
Development of Investment Attractiveness of Oil and Gas Region in Terms of Economical Instability
}

Lyubov L. Bogomolova

Renat K. Araslanov

Alena B. Shumeyko

Andrey V. Buzmakov

Yugra State University Khanty-Mansiysk autonomous district - Yugra

Email: I_bogomolova@ugrasu.ru

\section{Doi:10.5901/mjss.2015.v6n3p221}

\section{Abstract}

At the present moment the assessment of investment attractiveness of oil and gas regions is a crucial scientific and practical task. The paper analyzes development issues of investment attractiveness of oil and gas regions under sanctions and discovers main development trends, current state and prospects of investment attractiveness of Khanty-Mansi Autonomous Okrug - Yugra. A risk assessment is performed and an authors' model of classification of regions by their investment attractiveness is elaborated in the research. An assessment of investment activity is made and mid-term strategic development trends of investment attractiveness are set. Research objective: to make an assessment of investment attractiveness development of a sector-specific region and to substantiate mid-term strategic development priorities of Khanty-Mansi Autonomous Okrug - Yugra. The authors developed a group of activities, aimed at innovative development and hi-tech support has been developed.

Keywords: investment attractiveness, investment climate, investment risk, investment potential, development, regional economics, forecast, priorities, strategy, oil and gas regions.

\section{Introduction}

Present-day economic realities which reflect intense political nature of modern economic affairs in the world force regions' and countries' leaders to search for more effective ways to attract investors to their governorships by means of promotion and development of the investment attractiveness of the region.

In terms of economical instability and sanctions applied a special importance is given to regions that are able to promptly reorganize their economies to develop resource potential which is capable of providing population with ownproduced goods and services. Due to recent geopolitical developments Khanty-Mansi Autonomous Okrug - Yugra has faced new tasks and objectives which are meant to maintain high standard of human well-being based on balanced sustainable economic development, import substitution of goods, labour and services.

The investment attractiveness is susceptible the most to innovation development, introduction of new goods, their manufacturing technology and consumer promotion technology. An increase in volume of innovative product considerably ensures the stabilization of the economic growth of the region. An improvement of the quality of life of Yugra population depends directly on the investment attractiveness of the region and both internal and external investments. With all that in terms of sector-specific economic development the increase of investment attractiveness of the region will promote an economic diversity, and the government support for the development of the investment attractiveness will play a key role in this case.

\section{Research Methodology and Methods}

Goal of this research work reviews different approaches to the assessment of regions basing on their investment attractiveness, determines methods associated with the issue under inquiry, determines theories that can be taken as a basis for the forming category "investment attractiveness". Basing on the analysis of the investment attractiveness of the 
particular oil and gas region a choice of assessment criteria has been proved and the classification of regions by their investment attractiveness has been suggested. The following methods were employed in the research: logical: a morphological analysis and a Delphi method, a method of situational analysis and forecast; formal: classical methods of economic analysis and statistics, e.g. traditional methods of economic statistics, methods of decision theory.

Khanty-Mansi Autonomous Okrug - Yugra is the main oil and gas region of Russia and one of the major oil and gas regions in the world. It is the donor region and takes a lead in several basic economic performances which are oil production, electric power production, industrial production output, natural gas production. Organizations of the autonomous okrug form a substantial part of the Russian economy, this is about 7,5\% of industrial production and $15,1 \%$ of government budget revenue. The share of Khanty-Mansi Autonomous Okrug - Yugra in all-Russian oil production volume in 2013 was $48 \%$.

104 oil and gas companies, 6 oil refineries, 8 gas refineries and 1 condensate stabilization plant operate within the territory of the okrug. The region's share in total output of gas production in Russia is 5\%. In 2013255,1 million tons of oil and 33,0 billion $\mathrm{m}^{3}$ of associated petroleum gas were produced.

Khanty-Mansi Autonomous Okrug - Yugra is an export-oriented region and its export accounts for $95,6 \%$ of the overall volume of foreign trade turnover when import accounts for $4,4 \%$. Crude oil is $99,4 \%$ of the overall export volume. Import of goods and services into the region increased by $8,4 \%$ within the last year (21). Khanty-Mansi Autonomous Okrug - Yugra is the sector-specific oil and gas region with a limited number of basic industries in the structure of the regional economy and well developed additional and auxiliary industries.

\section{The Main Part of Research}

The investment attractiveness of Khanty-Mansi Autonomous Okrug - Yugra has typical regional features because it depends on the local market structure and the demand existing within the region's territory. In this connection the necessity to improve a mechanism of governmental support for the investment attractiveness becomes top-priority. This mechanism combines elements of federal, regional and municipal levels in strategic chain of command for each industry which ensures the development of a favourable investment climate within every territory and the adaptation of its facilities to the terms of separate industries. Thus, northern regions have their own specific peculiarities associated with an extensive use of hydrocarbon resources, severe climate, personnel shortage in socially important industries and absence of optimal logistics of goods and resources, all of this increases investment risks and serve as a deterrent for the development of the investment attractiveness of the region in general.

The investment attractiveness as a set of criteria that induce investors to invest the capital in this industry with favour (Kuzbozhev E.N. Kozieva I.A., 2003). is supposed to classify regions by certain characteristics into one or another type of state of regional economic development. The classification of regions developed by the European Economic Community (EEC) (fig. 1) (Shchiborshch K.B., 2003) strictly divides all the regions into 3 types: a region with stable economy, an economically stagnant region and a region with an average economic development. This division is a main decision-making reason for investors to invest.

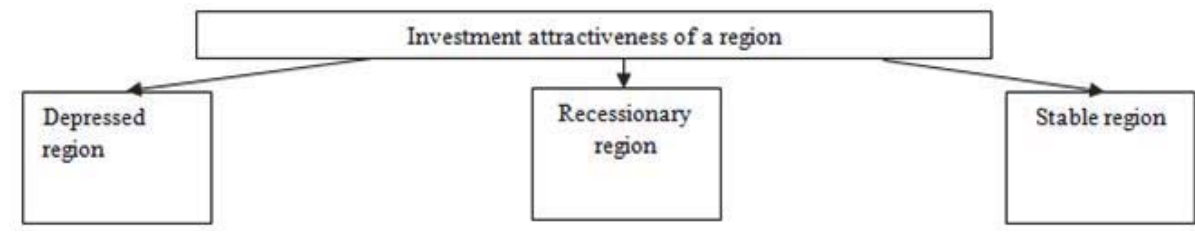

Figure 1. The EEC classification of regions by investment attractiveness.

According to the EEC classification depressed regions are the ones with uncertain prospects and negative development trends, they are at a standstill and growth rate tends toward a zero point. An income from investments in these regions is well below the average level in the country.

Recessionary regions are the territories which experience the decline of industrial production and social-economic development. The capital investment rate of return is difficult to assess.

Stable regions are economically sustainable regions. There are positive forecasts for changes in industrial production. The investment income may be above the average within the country (Shchiborshch K.B., 2003). When making a decision to invest, such a strict division provides only $33 \%$ selection of a region with a stable economy and that 
as experience shows is not quite fair to recessionary regions which have reserves for stabilization.

The authors of this paper suggest more detailed region assessment model according by the investment attractiveness level, (Bogovolova L.L., Buzmakov A.V., 2014).

Table 1. Region classification by the investment attractiveness level

\begin{tabular}{|c|c|}
\hline Classifier & Attribute \\
\hline 1. New region & $\begin{array}{l}\text { A region where all types of manufacturing are underdeveloped, home-made products and technologies } \\
\text { are either at the design or laboratory testing stages at best. Financial investment in this region is of a } \\
\text { high risk but these risks may be covered by excess return on investments and opportunity to capture } \\
\text { local market. From the ordinary investor's point of view this region is not preferable for investment. }\end{array}$ \\
\hline 2. Advancing region & $\begin{array}{l}\text { Together with types of manufacturing which are currently at the design stage there is a number of types } \\
\text { of manufacturing which are already at the industrial production stage. The region's risk and revenue are } \\
\text { more balanced due to current developments occurring in operating enterprises. }\end{array}$ \\
\hline $\begin{array}{l}\text { 3. Region with stable } \\
\text { growth }\end{array}$ & $\begin{array}{l}\text { This type of region is characterized by a large quantity of enterprises having set up industrial production } \\
\text { and successful work both on regional and federal markets. A series of products (including technologies) } \\
\text { goes for export. Both revenue and risk levels are average within the country. }\end{array}$ \\
\hline 4. Stagnation region & $\begin{array}{l}\text { Regions where a number of enterprises which introduce new technologies is decreasing. A connection } \\
\text { between research centers and manufacturing is weakening. Outdated and obsolete products are } \\
\text { produced. Current demand for products is maintained basically by domestic consumption, the export } \\
\text { volume is decreasing. An investment inflow is provided mainly by already existing enterprises. The } \\
\text { production and revenue levels are still high enough but investment in these territories is not } \\
\text { recommended since there are obvious trends for recession and increase of risk for capital investments } \\
\text { in the long-term. }\end{array}$ \\
\hline $\begin{array}{l}\text { 5. Region with stable } \\
\text { recession }\end{array}$ & $\begin{array}{l}\text { Regions that do not produce new types of products and do not introduce new technologies and } \\
\text { facilities. Some manufactures are either closed or transferred to other regions. A number of enterprises } \\
\text { introducing new technologies and facilities is approaching a zero point. The product export is practically } \\
\text { not performed. The investment inflow volume in the region is declining. The revenue and risk levels are } \\
\text { in inverse proportion to the constant growth of the latter. }\end{array}$ \\
\hline 6. Depressed region & $\begin{array}{l}\text { Regions with recession trends in industrial production. There is a weak or missing connection between } \\
\text { research centers and manufacturing. The investment level is the lowest amongst all types of regions } \\
\text { and is of a random character. The infrastructure for attracting new investors is poor. The risk level is } \\
\text { high which does not guarantee possible high revenue level. }\end{array}$ \\
\hline
\end{tabular}

A region-specific economic stability of Khanty-Mansi Autonomous Okrug - Yugra is substantially affected by market conditions on the international fuel and energy market, this has a negative impact on the overall investment attractiveness of the region and plays an important role for prospective investors who invest not in oil or gas producing industry (Deryabina Y., 2003).

In 2013 over 69 projects with a total amount of 580,7 billion roubles were implemented in Khanty-Mansi Autonomous Okrug - Yugra.

Table 2. Investment activity of Khanty-Mansi Autonomous Okrug - Yugra.

\begin{tabular}{|lcccc|}
\hline Industries & $\begin{array}{c}\text { Number } \\
\text { of projects }\end{array}$ & $\begin{array}{c}\text { Investment capacity of } \\
\text { projects,mln. rub. }\end{array}$ & $\begin{array}{c}\text { Includes implemented, } \\
\text { mln. rub. }\end{array}$ & $\begin{array}{c}\text { Share of total } \\
\text { investment volume, \% }\end{array}$ \\
\hline Petrochemical cluster & 35 & 133467,5 & 110663,625 & 22,98 \\
Electric power & 4 & 321404,00 & 103585,00 & 55,34 \\
Timber cluster & 9 & 10232,464 & 4721,96 & 1,76 \\
Construction & 11 & 21343,55 & 21343,55 & 3,67 \\
Ore mining cluster & 1 & 5270,00 & 5270,00 & 0,90 \\
Public Private Partnership (PPP) development & 4 & 86767,12 & 42216,00 & 14,94 \\
Solid household waste (SHW) recycling & 1 & 493,00 & 493,00 & 0,08 \\
Agriculture & 3 & 1679,18 & 1679,18 & 0,29 \\
Food processing industry & 1 & 50,00 & 50,00 & 0,04 \\
Total: & 69 & 580706,814 & 290022,31 & 100 \\
\hline
\end{tabular}

Khanty-Mansi Autonomous Okrug - Yugra belongs to the group of regions with sustainable growth: the investment volume is increasing, new technologies are being introduced, flagship products are going for export. The peculiarity is 
that the high investment attractiveness is ensured by its abundant natural reserves and as the result by its economic activity namely in the sector of natural resources management.

It is also important to take into account that Khanty-Mansi Autonomous Okrug - Yugra is one of the drivers of the Russian economy being a main supplier of the high value resource - hydrocarbons. According to the statistics of 2013 Khanty-Mansi Autonomous Okrug - Yugra ranks first in oil production including gas condensate with $51,1 \%$ of the total volume, first in electric power generation with $7,9 \%$ of the total volume, second in natural gas production $4,7 \%$ of the total volume and second in industrial production with $7,6 \%$ of the total volume (The report on social and economic development of KMAO-Yugra in 2013).

General profile of companies operating within the okrug territory considerably affects the industrial trend of the regional economy. The structure of the gross regional product (GRP) clearly represents present-day economy of KhantyMansi Autonomous Okrug - Yugra as the sector-specified (Bogomolova L.L., Buzmakov A.V., 2013).

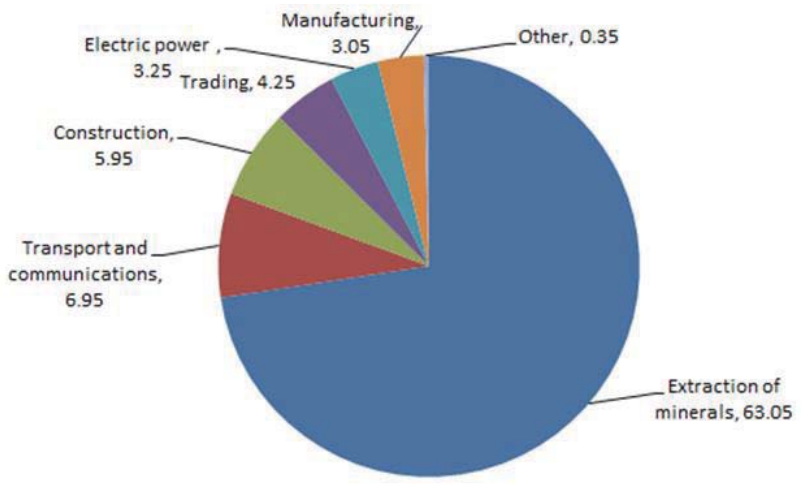

Figure 2. The GRP structure of KhMAO-Yugra in 2012

The natural resources industry i.e. the extraction of minerals accounts for $63,05 \%$ which is the largest share in the Gross Regional Product of the region. The second and third places are taken by "Transport and communications" and "Construction" with 6,95\% and 5,95\% respectively. Low shares of these industries in the GRP structure does not mean low mobility of population, slow pace of housing development or low development level of transportation. These are highly developed industries. They are attendant and serve to maintain the basic regional industry i.e. the hydrocarbon production as well as to bring additional income for the region. "Trading" and "Electric power" with 4,25\% and 3,25\% respectively are on the fourth place. Extensive expenditures for transport services, underdeveloped infrastructure and scarce logistics opportunities for entrepreneurs in this industry retard trading development. As for the electric power industry, individual persons and several oil-and-gas companies are among the end consumers of this developed industry. Quite a few major electricity consumers namely oil and gas companies produce it themselves. Based on such a severe imbalance in the economy structure of Khanty-Mansi Autonomous Okrug - Yugra the investment risk detection and analysis are extremely significant question for investors.

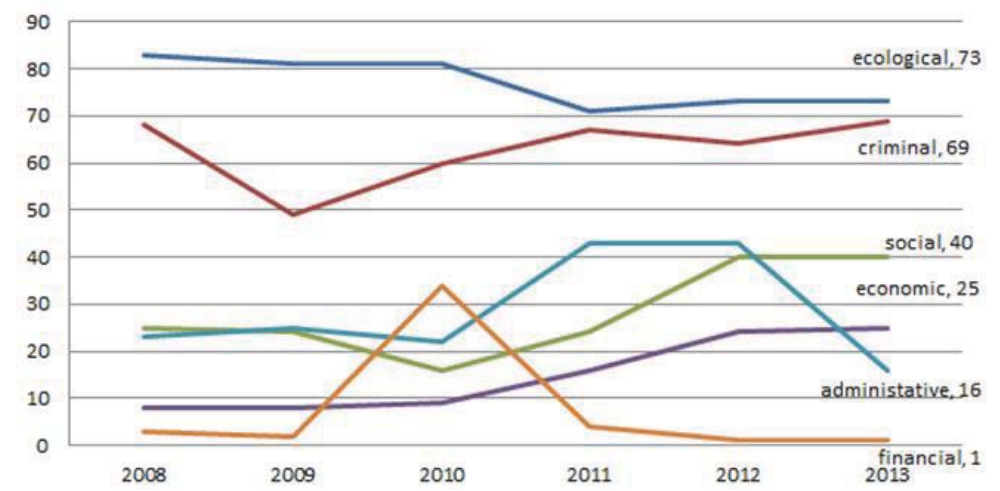

Figura 3. Components of the investment risk in Khanty-Mansi Autonomous Okrug - Yugra in 2008-2013 (Rating agency "Expert RA") 
The ecological risk in Khanty-Mansi Autonomous Okrug - Yugra has been the most acute issue in the region within the last 6 years. First of all it is associated with a specific nature of the industrial production which in its turn is connected with a high risk of environmental disasters. Among economic activities the major contribution to pollutant emissions is made by the "extraction of minerals" section which accounts for 70-82\% in 2008-2012 and the "transport and communications" section with $10-24 \%$. With all that there is an increase of pollutant emissions made by transport and communications which occurs against the background of decreasing tendency for the extractive industry (The official web-site of public authorities of Khanty-Mansi Autonomous Okrug - Yugra).

Oil and petroleum derivatives are the main environmental pollutants when extracting and transporting hydrocarbons. There has been a considerable growth of average annual hydrocarbon concentrations (petroleum derivatives) within recent years, moreover the number of measurements taken which exceed the background values is up to $20 \%$ of the sampling, but soils within license blocks can be regarded as non-polluted, that is to say that hydrocarbon concentrations are less than 500 mglkg (The decree of the Government of Khanty-Mansi Autonomous Okrug - Yugra № 410).

Criminal risk comes the second among the investment risks in Khanty-Mansi Autonomous Okrug - Yugra. The migrant stream is likely to become a real menace to the social stability. A substantial growth of migration activity is typical for the region. In 201361722 foreign residents arrived in the autonomous okrug which is $16,2 \%$ more in comparison with 51718 residents in 2012 . With all that 53494 foreign residents departed in a given period of time, it is $18,8 \%$ more in comparison with 43437 residents in 2012 (The report on social and economic development of KMAO-Yugra in 2013). Along with aliens having arrived the number of crimes committed by them increased by $11 \%$. Moreover downward dynamics of crimes is also maintained by indigenous peoples of the North, the rise in crime was 15\% in 2013 (Analytical memorandum, 2013).

Social risk in Khanty-Mansi Autonomous Okrug - Yugra is significantly lower than ecological and criminal ones and takes the $3^{\text {rd }}$ place among all investment risks. However the social risk has grown almost 2 times within the past 2 years. Due to the negative geopolitical situation and the oil price downturn a lot of programs are being cancelled. The region budget for 2015 has been enacted provided that all social obligations to the society will be fulfilled.

A situation on the region's labor market caused by the extensive employment of the expat workforce remains quite acute. An employers' pent-up demand on the labor market, an inability to use Russian workforce due to a disparity of supply and demand for the workforce, i.e. a discord between the occupational structure of unemployed citizens and open positions available stimulate employers to employ foreign residents.

In 2013 a quota for issuing alien work permits in Khanty-Mansi Autonomous Okrug - Yugra included 50786 permits which is 16,0\% less in comparison with 60545 permits in 2012 (The report on basic performance results, 2013).

Economic risk is also rather high and has got a growth trend over the past years. The regional economy is resource-based, it means its development fully depends on mineral resources produced and world market prices. Every year the situation becomes more tense due to a natural depletion of the regional resource base. In every oil and gas region the largest deposits are discovered and developed above all others but in course of time the scale of discoveries declines (The decree of the Government of Khanty-Mansi Autonomous Okrug - Yugra № 512).

Despite the systematic decrease of the well flow rate and the depletion of producing fields local authorities constantly try and involve additional resources to diversify the economy (The list of valid subsoil licenses, 2014).

The geopolitical situation has significantly affected the results of the 2014 fiscal year but the region has enough reserves to stabilize the economy and in the mid-term prevent the reduction of the economic development indicators.

Administrative risk has reduced considerably within the past 5 years. This is associated with development and initial application of numerous programs like "New school of Yugra", "Employment promotion in Khanty-Mansi Autonomous Okrug - Yugra in 2012-2014", "Efficiency improvement of budgetary expenditures in Khanty-Mansi Autonomous Okrug - Yugra over a period till 2014", "Small and medium enterprise development in Khanty-Mansi Autonomous Okrug - Yugra in 2011-2013 and till 2015", "Social and economic development, investment and innovations in Khanty-Mansi Autonomous Okrug - Yugra over a period of 2014-2020" and many others which will be successfully completed despite the negative economic trends.

The regional budget management has come up to the brand new level of performance: the budget of the autonomous okrug for 2014-2016 has been formed in the structure of state-run programs, this will allow to increase responsibility and interest in executives of state-run programs to achieve results under limited financial resources. 25 state-run programs arranged into 3 business areas are supposed to be completed in 2014-2016. The programs' expenses are more than $96 \%$ of total budget expenditures (Methodological instructions (recommendations) of the Department of Finance).

Financial risk is the lowest one of all risks reviewed. This is explained by fiscal capacity of all programs being 
implemented in the region and by well balanced budget itself as well.

In 2013 the budget revenue of the autonomous okrug was 136 684,5 million roubles which is 100,1\% in the amended annual plan. The amended annual plan for tax revenue was not implemented by 340,6 million roubles or $0,3 \%$, it is for corporate tax mainly. With all that several tax revenues were ahead of the target figures: an individual income tax was over by 267,1 million roubles, a corporate property tax was over by 6,6 million roubles (The report on performance results, 2013).

Analyzing the structure of the economic activity of the region it becomes obvious that for decades of the regional economy development the top-priority goal has been to maintain the oil and gas sector of the regional economy being an intense source of both regional and federal budget replenishment. Conditions for other industries and investment projects were being created after all the others. The situation has changed over the last years when special programs concerning agricultural development, tourism, construction and other fields of investment activity for economic diversity purposes were launched and realized.

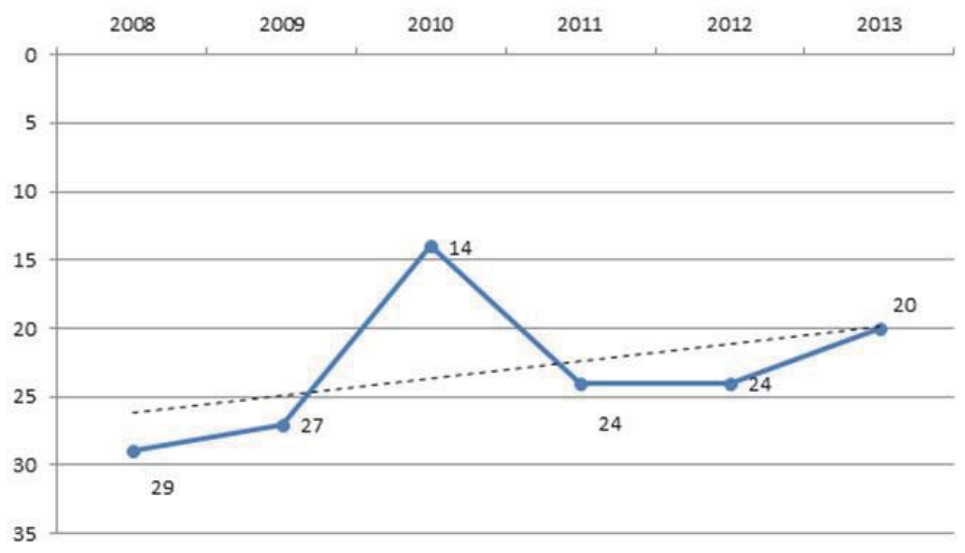

Figure 4. Investment risk rating in Khanty-Mansi Autonomous Okrug - Yugra in 2008-2013.

The investment risk rating in Khanty-Mansi Autonomous Okrug - Yugra displays the aggregate level of risks that prospective investors might come across within this territory. From 2008 till 2010 the rating remained on a comparatively low level for the region. In 2010 the rating grew substantially owing to adopting essential target programs aimed to improve the investment climate in the region. These programs are "Agroindustrial complex development of Yugra in 2011-2013 and for the period till 2015", "Development of the forest industry complex of Yugra in 2011-2013", "Development of the investment attractiveness of Yugra in 2011-2013" and others. But the developments happened within the following years showed that the effectiveness of a program-target method for the regional economy development did not prove itself properly in the first year when the programs were launched. The year of 2013 was marked with establishing an investment fund in Khanty-Mansi Autonomous Okrug - Yugra. Its purpose is to finance infrastructure facilities so crucial for investors to implement investment projects; and projects stipulated by concessionary agreements. The establishment of the investment fund has a positive effect on the investment risk level of the region having raised it by 4 points and ranked 20 (The investment rating of Russian regions).

The investment risks analysis revealed that in the long-term the risks would decline due to effective measures to create favourable environment for investment projects of different scale and to achieve positive results from already adopted programs and measures designed to develop the investment attractiveness of the region.

The investment dynamics will be characterized by the outstripping growth of private investments in comparison with the government ones. In general the investment growth of the natural resources sector will not exceed the growth of other private investments over the period. However the mid-term investment growth path will be defined largely by the investment dynamics of the fuel and energy complex.

In the basic variant the investment increase is estimated as 1,3\% in 2012, 1,0 \% in 2013, 3,1\% in 2014 and 1,8\% in 2015. 
Table 3. Growth rate of fixed investment

\begin{tabular}{|lccccc|}
\hline Parameter type & 2011 & 2012 & 2013 & 2014 & Forecast 2015 \\
\hline Fixed investment - total & 119,3 & 101,3 & 101,0 & 103,1 & 101,8 \\
Oil and gas complex & 111,1 & 100,7 & 100,5 & 100,7 & 101,0 \\
Manufactures & 70,4 & 100,3 & 101,0 & 101,0 & 101,2 \\
Power industry & 130,2 & 103,0 & 102,0 & 104,0 & 104,0 \\
Transport and communications & 78,6 & 100,0 & 100,5 & 101,5 & 101,0 \\
Education & 85,0 & 100,0 & 100,5 & 101,0 & 100,5 \\
Health care & 68,0 & 101,0 & 101,0 & 101,0 & 101,0 \\
Construction complex & 99,5 & 100,0 & 102,0 & 101,5 & 100,7 \\
\hline
\end{tabular}

Within the forecast period the construction of new low-power plants will start in the region. The mid-term investment policy priorities are projects involving associated petroleum gas processing.

Fixed investments in education and healthcare will increase moderately both in budget (more than by $10 \%$ annually in nominal terms) and private expenditures. Education and healthcare shares in the total volume of investments will have increased from 1,1\% in 2011 to 1,3\% by 2015.

In general, the share of budgetary investment in the investment structure will decrease (from 4,5\% in 2011 to 3,4 $\%$ in 2015). Budgetary funds will be allocated to community facilities and housing programs of the region.

In the mid-term the investment share of companies' own expenses will increase in the investment structure because of stimulation of enterprises to contribute their income to the production modernization (investments due to profit will increase by $8,0-10,0 \%$ annually in nominal terms) and improvement of proper use of amortization deductions.

During the forecast period of 2015 investments from bank loans and other sources will make a remarkable contribution to the total amount of raised funds; funds obtained from participation interest in housing construction (organizations and population) (The decree of the Government of Khanty-Mansi Autonomous Okrug - Yugra, 2012).

\section{Discussion}

The Government of Khanty-Mansi Autonomous Okrug - Yugra pays great attention to upgrading the investment attractiveness of the region having undertaken various events and measures to stabilize the regional economy. The target-program method serving to improve the investment climate and to reduce investment risks is supposed to elaborate different programs and legal acts.

Thus, to create a favourable investment climate of the Performance standard for executive authorities of KhantyMansi Autonomous Okrug - Yugra in order to provide a favourable investment climate in the autonomous okrug was elaborated and implemented. The standard serves to improve the investment climate in Khanty-Mansi Autonomous Okrug - Yugra and taking into account the best regional practices to provide necessary conditions for enhancing the investment inflow into the region, business and authority interaction, improving transparency of entrepreneurship support system.

It should be noted that a series of events within the framework of the Standard have already completed. Particular measures have been taken to enhance regulatory legal acts on elimination of ungrounded administrative barriers which obstruct to perform investment activity and to establish transparency of government support for the investment activity. As the result the Law of the autonomous okrug of March, 31, 2012 № 33-0z "On government support for investment activity in Khanty-Mansi Autonomous Okrug - Yugra" has been passed, the Council of the Government of Khanty-Mansi Autonomous Okrug - Yugra on issues of the investment activity development in Yugra has been established, a special bilingual web portal about the investment activity in Yugra is being created. To support the investment attractiveness of the region mechanisms of financial support in the form of government guarantees have been formed; subsidies for partial expenditure compensation of construction of utility networks and engineering infrastructure; subsidies for partial expenditure compensation of interest payment for attracted loans; favourable stimulating tax climate is ensured.

A group of actions aimed at innovative development and hi-tech support has been designed. It suggests the investment attractiveness development of the region for the next year of 2015 and includes maintenance and implementation of the technical platform and innovative organizations, development of the infrastructure which actuates "an innovative elevator", stimulation of innovation activity in companies, support for innovation activity in organizations, implementation of the Concept of the innovation activity in Khanty-Mansi Autonomous Okrug - Yugra until 2020 (The report on results, 2013). 


\section{Results}

Summarizing the results of the research conducted we can notice that classification criteria for regions by their investment attractiveness suggested in this paper will offer a proper orientation for investors to invest successfully and be of a practical use i.e. it will find practical application. Parameters for region classification by the investment attractiveness may be regarded as investment development criteria for territories with different resource potential but approaches to the assessment of investment risks reviewed in this research will encourage investors to invest into the regional economy. The results of the scientific research are among the following:

- The economic assessment of the resource potential of Khanty-Mansi Autonomous Okrug - Yugra has been performed;

- The economic assessment of the investment attractiveness of the oil and gas region has been performed;

- The investment risks have been economically feasible;

- Strategic priorities of the investment activity development in Khanty-Mansi Autonomous Okrug - Yugra have been set;

- Activities of the government support for the investment attractiveness development of the region and favourable investment climate creation have been reviewed.

\section{References}

Bogovolova L.L., Buzmakov A.V. (2014) Economical assessment of the development of the investment attractiveness of the region: innovative constituent. // Humanities, economics and social sciences. All-Russian scientific journal №3, 2014.

Bogomolova L.L., Buzmakov A.V. (2013) Investment attractiveness of KMAO-Yugra. // International research and scientific conference proceedings Sworld "Scientific researches and their practical application. Present state and development paths 2013". - I.3. Vol.37. Odessa: KUPRIENKO SV.

Ways of oil and mining potential implementation in Khanty-Mansi Autonomous Okrug - Yugra: 10th research and scientific conference [sourcebook] (2007). // The Government of KMAO, the Department for Oil, Gas and Mineral resources of Khanty-Mansi Autonomous Okrug - Yugra, State own enterprise of KMAO "V.I.Shpilman research and analytical Centre for the rational use of the subsoil"; as amended by Karasyov V.I., Shpilman A.V., Volkov V.A. Khanty-Mansiysk. IzdatNaukaServis. Vol. 4, - 454 p.

Investment passport of Yugra. Official website of the Department of Economic Development of Khanty-Mansi Autonomous Okrug - Yugra. Available at: http://www.depeconom.admhmao.ru.

Kuzbozhev E.N. Kozieva I.A. (2003). Economic geography and regional studies. - Kursk: Kursk State Technological University, 2003. - P. 78.

Shchiborshch K.B. (2003) Assessment of the investment attractiveness of an industry. // Adviser of director. № 12. - P.7.

Deryabina Y. (2003) Comparative analysis of approaches to the investment attractiveness assessment and the investment activity of regions. // Investments in Russia. - № 8. - P. 13.

The report on performance results of the Department of Finance of Khanty-Mansi Autonomous Okrug - Yugra in 2013. Available at: http://admhmao.ru.

Methodological instructions (recommendations) of the Department of Finance. Available at: http://admhmao.ru.

The decree of the Government of Khanty-Mansi Autonomous Okrug - Yugra №410 On government program of Khanty-Mansi Autonomous Okrug - Yugra "Development and utilization of mineral resources base of Khanty-Mansi Autonomous Okrug - Yugra in 2014-2020". Available at: http://admhmao.ru.

The list of valid subsoil licenses for geological exploration, surveying, and mining of widespread mineral deposits in 2014. Available at: http://admhmao.ru.

The report on social and economic development of KMAO-Yugra in 2013. Available at: http://admhmao.ru.

The report on basic performance results of the Department of Labour and Employment of Khanty-Mansi Autonomous Okrug - Yugra in 2013.

The investment rating of Russian regions. // Rating agency "Expert RA". Available at: http://raexpert.ru.

The research "Investment attractiveness rating of regions". // Rating agency "Expert RA". Available at: http://raexpert.ru.

The social and economic development strategy of Khanty-Mansi Autonomous Okrug - Yugra until 2020 and for the period until 2030.

The decree of the Government of Khanty-Mansi Autonomous Okrug - Yugra № 512-rp On social and economic development forecast of KhantyMansi Autonomous Okrug - Yugra for 2014 and target period of 2015-2016.

Analytical memorandum of Administration of the Ministry of Internal Affairs of the Russian Federation for Khanty-Mansi Autonomous Okrug Yugra on performance results of protection of public order and security protection in Khanty-Mansi Autonomous Okrug - Yugra and also measures taken to provide public confidence and social support in 2013. Available at: http://86.mvd.rul.

The report on results and main fields of concern of the Directorate of the Federal Migration Service for Khanty-Mansi Autonomous Okrug - Yugra in 2013 and target period of 2014-2016.

The report on ecological situation in Khanty-Mansi Autonomous Okrug - Yugra in 2013 of the Department of Ecology of Khanty-Mansi Autonomous Okrug - Yugra.

The official web-site of public authorities of Khanty-Mansi Autonomous Okrug - Yugra. Available at http://www.admhmao.ru/people/ frame.htm (access date 06.10.2014).

The decree of the Government of Khanty-Mansi Autonomous Okrug - Yugra of October 13, 2012 № 615-rp On social and economic development forecast of Khanty-Mansi Autonomous Okrug - Yugra for 2013 and target period of 2014-2015. 